\title{
Synthesis of Nano-film from Nanofibrillated Cellulose of Banana Pseudostem (Musa spp.) to Extend the Shelf life of Tomato
}

\author{
Ponnudurai Ponni, ${ }^{\mathrm{a}}$ Kizhaeral S. Subramanian, ${ }^{\mathrm{a}, *}$ Gnanaguru Janaki Janavi, ${ }^{\mathrm{b}}$ and \\ Jayasankar Subramanian ${ }^{\mathrm{c}}$
}

\begin{abstract}
A nano-film was developed using nano-fibrillated cellulose (NFC) obtained from banana (var. Poovan) pseudostem. The NFC was prepared by alkali treatment followed by bleaching and acidification, as described and characterized in the authors' previous paper. The NFC was used as base material for the development of nano-film. The nanofilm was prepared via solvent casting with NFC (4\%), polyvinyl alcohol $(5 \%)$, and polyacrylic acid (5\%) at a $\mathrm{v} / \mathrm{v}$ ratio of $5: 8: 1$. The nano-film was characterized using ultraviolet-visible (UV-VIS) spectroscopy, Fourier transform infrared (FT-IR), thermal gravimetric analyzer, scanning electron microscopy (SEM), gas permeability tester (GPT), texture profile analyzer, and digital thickness gauge meter. The data showed that the developed nano-film was UV protectant, possessed strong cross-linking, had high oxygen barrier capacity, was thermally stable up to $356{ }^{\circ} \mathrm{C}$, and had high tensile strength than conventional film. To assess the protective quality of developed nano-film, tomato fruits were covered, and the shelf life was determined using physiological and biochemical attributes. The study revealed that nano-film developed from NFC possessed tomato preserving capacity for 15 days under ambient storage condition. Overall, the data suggested that banana fibres could be a potential source of NFC to develop biodegradable nano-film.
\end{abstract}

Keywords: Banana pseudostem; Cellulosic waste; Nanofibrillated cellulose; Nano-film; Shelf life; Tomato

Contact information: a: Department of Nano Science \& Technology, Tamil Nadu Agricultural University, Coimbatore 641003, India; Director of Research, Tamil Nadu Agricultural University, Coimbatore 641003, India; b: Department of Vegetable Science, Horticulture College and Research Institute, Periyakulam East, Theni 625 604, India, c: Tree Breeding, Vineland 4890 Victoria Avenue North Vineland Station, Ontario, LOR 2EO, Canada; *Corresponding author: kss@tnau.ac.in

\section{INTRODUCTION}

Nanotechnology is one of the most notable emerging fields of science explored in food packaging. Nanopackaging plays a pivotal role in reducing the post-harvest losses of fresh fruits and vegetables (He et al. 2016). Recently, it has been estimated that more than $40 \%$ of the packaging industry across the globe will use nanotechnology principles and concepts by the year 2020 (Singh 2016). Nano-films are being developed using several nanomaterials, such as a nanoclay polymer composite matrix (Trifol Guzman 2016) or those impregnated with antimicrobial factors, such as Ag nanoparticles (Carbone et al. 2016), chitosan (Aider 2010), or bacteriophages (Phisalaphong and Jatupaiboon 2008). The addition of nanoclays, such as montmorillonite, into packaging material the tensile properties, thermal stability, and stiffness were improved (Stiller 2008). These favourable characteristics in nano-film facilitate the extension of the shelf 
life of fruits and vegetables. Even though those nano-films extend the shelf life of fruits and vegetables, non-biodegradability is a major constraint. Some additive chemicals, such as tributyltin, phthalates, and bisphenol A (BPA), are mixed with polymers to improve the colour, softness, and flexibility of the packaging material (Meeker et al. 2009). Phthalates are added with polyvinyl chloride (PVC) to increase the flexibility (Oehlmann et al. 2009), while BPA is the monomer is used for the production of polycarbonate plastics (Talsness et al. 2009). Those additive chemicals are potentially toxic and they have adverse effects on the environment, cultivable land, and animal and human populations (Oehlmann et al. 2009). The use of those non-biodegradable plastics has increased every year by up to $5 \%$ and its production reaches 150 million tons per year (Braun 2004). In 2020, production of plastics is expected to exceed 300 million tons (Thompson et al. 2009).

To overcome the hazards, there has been a marked increase of interest in the use of biodegradable materials obtained from bioresources, such as cellulose, in packaging to protect and preserve fruits and vegetables. Cellulose is one of the most abundant homopolysaccharides consisting of $\beta$-D-glucopyranose units linked by a glucoside bond at their C1 and C4 hydroxyl groups (Paralikar et al. 2008). Cellulose derivatives possess excellent film-forming properties and cellulose-based films are great barriers to aroma, oxygen, and oil transfer, in common with other hydrophilic films. Derivatives of cellulose, such as methylcellulose and hydroxypropyl methylcellulose, form strong and flexible water-soluble films. The cellulose on earth is present in approximately $1.5 \times 10^{12}$ tons of annual biomass production (Klemm et al. 2005). The banana pseudostem (70 to 80 tonnes per ha) has a higher amount of cellulose (50 to 59\%), and is considered a waste material that can be effectively used to develop biodegradable films (Gopinathan et al. 2017).

To avoid the wastage of abundant cellulose, a novel approach to produce a nanocellulose material (Eichhorn et al. 2010) has been attempted. Nanocellulose has attracted attention due to its properties, including high surface area, high aspect ratio, high axial Young's modulus, low density, modifiable surface properties, ultraviolet (UV) illumination resistance, and higher biodegradability than its macroscopic form (Brinchi et al. 2013; Rajan et al. 2014). Gopinathan et al. (2017) have shown that the nanofibrillated cellulose (NFC) derived from banana genotypes is unique and distinct in its characteristics. The NFCs are UV resistant and thermally stable with high crystallinity that is suitable to develop a biodegradable nano-film intended for the storage of fresh fruits and vegetables.

Paralikar et al. (2008) developed a nano-film using polyvinyl alcohol (80\%) and cellulose nanocrystals (10\%) as substrates and polyacrylic acid (10\%) as a crosslinker. The nano-film possessed the highest tensile strength and was thermally stable when cellulose nanocrystals were added to prepare a barrier membrane. In another study, Zimmermann et al. (2004) developed a nano-film by reinforcing polyvinyl alcohol with hydroxypropyl cellulose, and the resultant film showed a three-fold increase in Young's modulus and five-fold increase in tensile strength compared to the base materials. To improve the decomposability of the nano-film, NFC from plant origin is being explored as a base material. Reinforcement of NFC with polyacrylic acid is known to improve the tensile strength and mechanical properties while reducing the hydrophilicity of crosslinked nanocomposite films (Spoljaric et al. 2013). The use of nano fibrillated cellulose has been extensively studied to improve the tensile properties of the film in 
comparison to wood-pulp-reinforced composites (Nakagaito and Yano 2005; Fujisawa et al. 2012; Al-Turaif 2013; Endo et al. 2013; Littunen et al. 2013).

Despite the fact that many nano-film related basic experiments have been conducted, use of the film as a smart packaging material has been rarely studied. The principle function of food packaging is protection and preservation of fruits and vegetables from external contamination. Fruits and vegetables are highly perishable because of their high water content. Among the vegetables, tomato (Solanum lycopersicum) is one of the most widely cultivated climacteric vegetables possessing a short shelf life of 4 to 6 days. The post-harvest losses of tomatoes has been estimated as 30 to $35 \%$ due to physical, physiological, and biochemical changes, and processes such as improper handling, packaging and storage, physiological process of respiration, ethylene release, reduction of weight, and firmness during ripening. To reduce the losses during storage, an increase in the shelf life of tomato is important for domestic and export markets.

Worldwide, various technologies have been adopted to minimize the post-harvest losses at various stages of storage and distribution; among such options, packaging technology is understood to provide better results. Rolle et al. (2006) stated that lowdensity polyethylene (LDPE) is used to wrap fruits and vegetables because of its high gas permeability and low water permeability properties. Various wrapping materials, such as polyethylene bags, newspaper, and grease-free papers, are used to extend the shelf life of fruits and vegetables, of which polyethylene bags performed better resulting in higher quality with longer shelf life of 28 days (Shahnawaz et al. 2012). Modified atmosphere packaging, high-density polyethylene (HDPE), and LDPE packaging of tomatoes under ambient and refrigerant conditions was evaluated to reduce the post-harvest losses of tomato due to changes in temperature and relative humidity in the atmosphere. The results revealed a higher weight loss in the control (unwrapped fruits), which was $11.7 \%$ and a lower weight loss was recorded in tomato wrapped in HDPE under refrigerant storage conditions $(1.67 \%)$. It was also found that the metabolic activity of the product slows down when the product is stored under low temperatures (Sualeh et al. 2016). In all the cases, studies were conducted on non-biodegradable materials.

The present study hypothesizes that the nano-film developed using NFC derived from banana pseudostem in combination with a hydrophilic polymer (PVOH) and compatibilizer (PAA). The nano-film was characterized using ultraviolet-visible (UVVIS) spectroscopy, Fourier transform infrared spectroscopy (FTIR), scanning electron microscopy (SEM), thermal gravimetric analyzer (TGA), gas permeability tester (GPT), texture profile analyzer, and digital thickness gauge meter. All the physical and biochemical parameters, such as physiological loss in weight (PLW), firmness, $\mathrm{pH}$, total soluble solids (TSS), titrable acidity (TA), ascorbic acid, total sugar, and reducing sugar were also analyzed in the experimental samples of tomato.

\section{EXPERIMENTAL}

\section{Materials}

The nano-film was prepared by a "solvent casting method" with the combination of NFC from banana (Musa sp.) pseudostem fibre (Department of Fruit Science, Tamil Nadu Agricultural University, Coimbatore, India), PVOH ( $M_{\mathrm{W}} 1,15,000$, Astron Chemicals, Ahmedabad, India), and PAA ( $M_{\mathrm{W}} 1800$, Sigma Aldrich chemicals Private 
Limited, Bangalore, India). The conventional film (MONTEX cling film; NK Enterprises, Haryana, India) was purchased to conduct comparative experiment with the nano-film. The $85 \%$ maturity and similar-sized tomato fruits were purchased from a local market, Coimbatore, Tamil Nadu, India to assess the protective quality of developed nano-film.

\section{Methods}

Synthesis of nano-film

The stock solution was prepared by blending 5\% PAA, 4\% NFC, and 5\% PVOH at the combination of 1:5:8. The blended solution was sonicated for 20 min by an ultraprobe sonicator (SONICS VCX 1500; Sonics \& Materials Inc, Connecticut, US) for complete dispersion. The solution was casted on a $140-\mathrm{mm}$ diameter petri plate and allowed to dry for approximately $40 \mathrm{~h}$. After completion of drying, the developed film was heat-treated in a hot air oven (ESCO ISOTHERM OFA-170-8; Esco, Singapore.) at $170{ }^{\circ} \mathrm{C}$ for $45 \mathrm{~min}$.

\section{Fruit sampling}

The tomatoes were packed in a Thermocol box wrapped separately with nanofilm, conventional film, and there was also a control (without wrapping). The observations of physiological weight loss $(\%), \mathrm{pH}$, firmness $(\mathrm{N})$, total soluble solids ( ${ }^{\circ}$ Brix), titrable acidity, ascorbic acid (mg/100 g), total sugar (\%), and reducing sugar (\%) were recorded at three- day intervals.

\section{Characterization and Analysis}

\section{$U V$-VIS transmittance studies}

The UV transmitting properties of the nano-film and conventional film were determined using an UV-VIS spectrophotometer (Specord plus 210; Analytik Jena, Jena, Germany), where Millipore water (Department of Nano Science \& Technology, Tamil Nadu Agricultural University, Coimbatore, India) was used as a blank. The samples were cut into $45 \mathrm{~mm} \times 10 \mathrm{~mm}$ size, and the samples were placed in the cuvette for UV irradiation that was emitted via mercury fluorescent lamps. The transmittance spectra were measured between 200 to $800 \mathrm{~nm}$.

\section{FT-IR analysis}

The presence of cross-linkage between NFC, PVOH, and PAA in nano-film, and the chemical bond present in a molecule of the conventional film were characterized using a Jasco FT-IR-6800 spectrometer (JASCO, Easton, Maryland, United States), KnowItAll ${ }^{\circledR}$ ID Expert software (Bio-Rad Laboratories private limited, Chennai, India). The samples were placed in $\mathrm{NaCl}$ crystal holder, and the transmittance spectra were recorded over the wavenumber range of 4000 to $400 \mathrm{~cm}^{-1}$ at a spectral resolution of 0.07 $\mathrm{cm}^{-1}$.

$T G A$

Thermal stability and decomposable ability of the nano-film and conventional film were determined using a thermal gravimetric analyzer (TGA SDT Q 600; Artisan Technology Group, Champaign, IL, USA) under a nitrogen flow of $100 \mathrm{~mL} / \mathrm{min}$. Approximately $5 \mathrm{mg}$ of sample was heat-treated from room temperature to $800{ }^{\circ} \mathrm{C}$ at a heating rate of $10{ }^{\circ} \mathrm{C} / \mathrm{min}$. The relation between temperature against the heat flow $(\mathrm{mW})$ 
and derived weight loss percentage denoted the stability and decomposable property of the sample.

\section{GPT analysis}

The oxygen and carbon dioxide permeability of nano-film and conventional film were determined using a manometric gas permeability tester (Model - LYSSY L1005000; Elixir Technologies, Bengaluru, India). The samples were cut to the size of $10 \mathrm{~cm}$ $\times 10 \mathrm{~cm}$. The samples were placed on gas rupture that was secured between two O-rings; the instrument operated under the pressure of lower means limit 500 psi and upper means limit of $700 \mathrm{psi}$ at a temperature of $23{ }^{\circ} \mathrm{C}$. The unit of results expressed in $\mathrm{mL} / \mathrm{m}^{2} \times$ day.

\section{Tensile strength}

Elongation and break-even point of nano-film and conventional film were measured using a texture profile analyzer (Stable Micro Systems TA.HD plus; Stable Micro Systems Ltd., Godalming, England). The machine used for the measurement was maintained at a constant rate of traverse of grip head. The samples were cut into a dogbone shape in strips of $15-\mathrm{cm}$ length and 1.5- to 2-cm width. One end of the strip was tightly gripped in the upper clamp, and the other end was in the lower clamp after adjusting the alignment to as straight as possible. The machine was switched 'on', and the cross-head speed was pre-adjusted to $1 \mathrm{~mm} \cdot \mathrm{min}^{-1}$. The result of each individual sample was recorded and the maximum elongation was calculated and expressed as $\mathrm{N} / \mathrm{mm}$.

\section{Thickness}

The thickness of the nano-film and the conventional film were measured using a gauge meter (Mitutoyo Digital thickness gauge H-2781; Mitutoyo, Leicester, England). Four various sides of the samples were measured. Thickness of the film was expressed in $\mathrm{mm}$.

\section{SEM analysis}

The surface of the nano-film and conventional film was observed using a scanning electron microscope (SEM) (Quanta 250; FEI Company, Eindhoven, Netherlands) with a high-energy beam of electrons. The samples were mounted on a specimen stub with double-sided conductive $\mathrm{C}$ tape. The observation was performed by the hitting of high-energy electrons through magnetic lenses that converted into secondary electrons, and it was collected by the detector as signals; then, the signals were amplified and translated into a surface image of the sample. Before characterizing, the samples were sputter coated with gold alloy for 15 seconds in an EMITECH SC7620 sputter coater (Quorum Technologies Ltd., Laughton, East Sussex, England).

\section{Physiological Weight Loss (PLW)}

The physiological weight loss of three tomato fruits from each sub-lots of five replications in each treatment $(n=15)$ was marked. The weight of the marked fruits was recorded periodically once every three days using an electronic weighing balance (Model- TTB 3; Wensar Weighing Scales Ltd., Chennai, India) and the PLW was expressed as a percent. The PLW was calculated using Eq. 1:

$$
\text { PLW }(\%)=\frac{\text { Initial weight }(\mathrm{g})-\text { Final weight }(\mathrm{g})}{\text { Initial weight }(\mathrm{g})} \times 100
$$




\section{Firmness}

The firmness of the fruits was measured by the use of a hand-operated penetrometer. Five tomato fruits from each treatment $(n=15)$ were marked. The instrument was penetrated to the depth of $1 \mathrm{~cm}$ at three different places viz., proximal, distal, and at the middle of the marked fruits. The values of firmness were expressed in Newton.

$p H$

One fruit from each box was picked randomly, and approximately $25 \mathrm{~g}$ of fruit pulp was macerated using a pestle in a mortar with $25 \mathrm{~mL}$ of distilled water. The final volume was made up to $250 \mathrm{~mL}$. The sample was filtered to remove the debris. Approximately $100 \mathrm{~mL}$ of the juice was then transferred to a $250-\mathrm{mL}$ beaker and the $\mathrm{pH}$ was measured using a $\mathrm{pH}$ meter (Model GLOBAL Digital $\mathrm{pH}$ meter DPH 500; Global Electronics, Hyderabad, India) after calibrating the electrode with a standard solution. Analysis was performed at 3 day intervals until the fruits became over-ripened and beyond use.

\section{Total soluble solids (TSS)}

Randomly elected fruits from the treated and control were used to determine the TSS content present in the fruits. A drop of clear tomato juice was placed on the prism of hand-held digital refractometer (HI 96801 HANNA Model; Hanna Equipments India Private Limited, Thane, India). The TSS contents were expressed as ${ }^{0}$ Brix.

\section{Titrable acidity}

Titrable acidity was determined using a titration method. A total of $25 \mathrm{~mL}$ of clear juice was taken from the sample and titrated against $0.1 \mathrm{~N} \mathrm{NaOH}$ using a phenolphthalein indicator with constant shaking. The appearance of light pink colour was marked as the end point of the reaction. Presence of acidity was calculated and expressed as \% citric acid.

$$
\text { Acidity }(\%)=\frac{\text { Titre value } \times \text { Normality } \times \text { Molecular equivalent weight of acid }}{\text { Volume of sample }} \times 100
$$

\section{Ascorbic acid content}

Five fruits were taken from each treatment for estimation of ascorbic acid. A total of $0.5 \mathrm{~g}$ of fruit sample was taken and macerated with $4 \%$ oxalic acid. After maceration, it was made up to $10 \mathrm{~mL}$ with distilled water. Then, the diluted sample was centrifuged at $400 \mathrm{rpm}$ for $15 \mathrm{~min}$, and $5 \mathrm{~mL}$ of supernatant solution was transferred to a $250-\mathrm{mL}$ conical flask, in that $10 \mathrm{~mL}$ of $4 \%$ oxalic acid was added. The sample solution $\left(\mathrm{V}_{1}\right)$ was titrated against 2, 6-Di chlorophenol dye $\left(\mathrm{V}_{2}\right)$. The appearance of pink colour was considered as the reaction end point.

$$
\text { Amount of Ascorbic acid }=\frac{0.5 \mathrm{mg} \times \mathrm{V} 2 \times 100 \mathrm{ml}}{\mathrm{V} 1 \times 5 \mathrm{ml} \times \text { Weight of the sample }} \times 100
$$

\section{Total sugars}

A total of $100 \mathrm{mg}$ of sample was added in $5 \mathrm{~mL}$ of $2.5 \mathrm{~N} \mathrm{HCl}$ for hydrolysis, which was kept in a boiling water bath for $3 \mathrm{~h}$. Then, the sample was cooled and centrifuged for $10 \mathrm{~min}$ at $400 \mathrm{rpm}$. The supernatant was collected and made up to 100 
$\mathrm{mL}$. From that, $1 \mathrm{~mL}$ was removed, and $4 \mathrm{~mL}$ of anthrone reagent was added in each test tube. Next, the tubes were heated for $10 \mathrm{~min}$ in a boiling water bath. After cooling of the sample, the intensity of green colour was read via UV- Vis spectroscopy at $625 \mathrm{~nm}$. Standards were also prepared by taking $0,0.2,0.4,0.6,0.8$, and $1 \mathrm{~mL}$ of the working standard $(0.1 \mathrm{mg}$ glucose per $\mathrm{mL})$. The ' 0 ' served as the blank that was also read under UV-VIS spectroscopy. A standard graph was drawn by plotting the concentration of the standard on the x-axis versus absorbance on the y-axis. From the graph, the amount of total sugar present in the sample tube was calculated. Total sugar was expressed as a percent.

\section{Reducing sugars}

Nelson-Somogyi's method was followed to quantify the reducing sugar of tomato fruits (Somogyi 1952). A total of $2 \mathrm{~g}$ of fruit pulp samples were macerated with $80 \%$ ethyl alcohol using a pestle and mortar. The extract was passed through two layers of cheesecloth. The extracts were finally filtered through Whatman No. 41 filter paper (Optics Planet Inc. Northbrook, IL, USA). The filtered sample was heated at $80{ }^{\circ} \mathrm{C}$. Afterwards, $10 \mathrm{~mL}$ of water was added to dissolve the sugars. A total of $0.2 \mathrm{~mL}$ of alcohol-free extract and working standards $(0,0.2,0.4,0.6,0.8$, and $1 \mathrm{~mL})$ was pipetted out to separate test tubes.

Both the sample and standard tubes were made up to $2 \mathrm{~mL}$ with distilled water. Then, $1 \mathrm{~mL}$ of alkaline copper tartrate reagent) (Sigma-Aldrich Chemicals Private Ltd., Bengaluru, India) was added to each tube, and the tubes were placed in boiling water for $10 \mathrm{~min}$. After cooling, $1 \mathrm{~mL}$ of arsenomolybdic acid reagent (Sigma-Aldrich Chemicals Private Ltd., Bengaluru, India) was added to all of the test tubes. All the tubes were made up to the volume of $10 \mathrm{~mL}$ with distilled water. After 10 min the absorbance was measured at $620 \mathrm{~nm}$ using the spectrophotometer (Specord plus 210), and the reducing sugar was expressed as a percent.

\section{Statistical analysis}

The obtained data were statistically analyzed using XL STAT software (Addinsoft, Paris, France). A completely randomized design (CRD) was employed to understand the main effects of treatments at different storage days and the changes in physiological and biochemical parameters of tomato fruits in the laboratory conditions.

The mean comparisons were made after computing an analysis of variance (ANOVA), standard deviation, and least significant difference (LSD) values with $\mathrm{P}<$ 0.05 level of significance.

\section{RESULTS AND DISCUSSION}

\section{UV-VIS Studies}

The transmittance of nano-film and conventional film was measured via an UVVIS spectrophotometer. The transmittance values were reported in the UV-VIS spectra (Fig. 1). It was observed that for the conventional film, the minimum transmittance was at $290 \mathrm{~nm}$, and the average transmittance percentage was 84. For the nano-film, the minimum transmittance occurred at $278 \mathrm{~nm}$ and the average transmittance percentage was 81 . The nano- film prepared using PVOH was uniformly distributed with NFC of size ranging between $80 \mathrm{~nm}$ to $105 \mathrm{~nm}$. Because of this uniform distribution and smaller 
size of NFC contributed to the increased surface area and efficiency of the nano-film than the conventional film ( 2 to $5 \mu \mathrm{m})$.

The presence of strong cross linkage and even distribution increase the efficiency of the nano film. This could be helps to prevent the transmittance of UV. From this, it was concluded that the nano-film made from NFC transmitted the UV-light at a lesser amount and minimized the UV-light induced lipid oxidation in the skin of fruits, which may extend the shelf life of perishables when compared to the conventional film (Gopinathan et al. 2017).

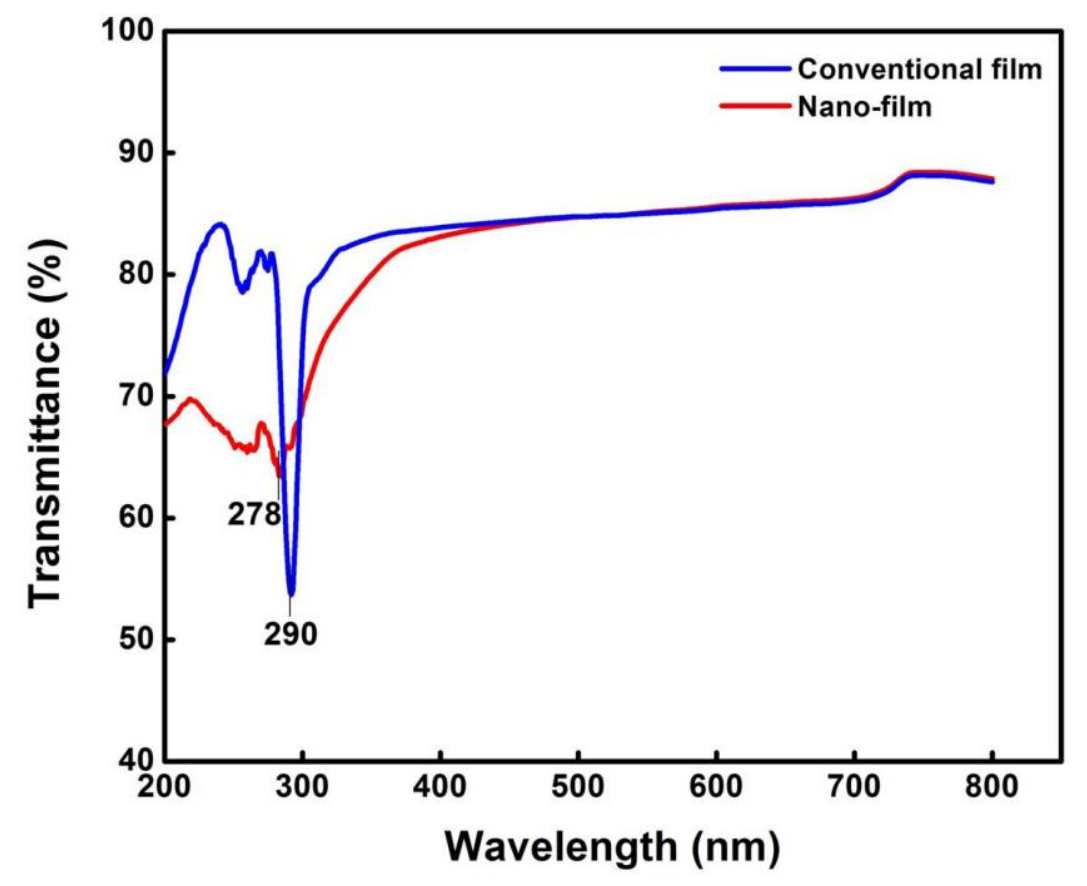

Fig. 1. UV-VIS transmittance studies of conventional film and nano-film

\section{FT-IR analysis}

The presence of chemical structure and cross-linkage of the nano-film and conventional film were investigated using KnowItAll@ ID Expert software (Bio-Rad Laboratories Private Limited, Chennai, India) in an FT-IR analysis. In conventional film, the presence of a peak at $2926 \mathrm{~cm}^{-1}$ confirmed that the conventional film was made up of poly(vinyl chloride). The presence of an acid group was indicated by a broad, strong absorbance at $2857 \mathrm{~cm}^{-1}$, denoting the aliphatic acid (PAA) was added as a compatibilizer of the conventional film. The stretched strong peak at $1720 \mathrm{~cm}^{-1}$ confirmed the presence of $\mathrm{O}-$ phthalate plasticizer in the film. The aromatic functional group was also present at $1426 \mathrm{~cm}^{-1}$.

The FT-IR spectra at $1093 \mathrm{~cm}^{-1}$ (C-O stretch) confirmed the presence of NFC in the nano-film. The peak at $3340 \mathrm{~cm}^{-1}$ denoted the alcohol group of hydrogen-bonded $\mathrm{OH}$ stretching of PVA. The presence of PAA was confirmed by the presence of acid functional group $(\mathrm{O}-\mathrm{H})$ of stretched, strong bond at the spectra of $2706 \mathrm{~cm}^{-1}$ (Spoljaric et al. 2013). The stretched strong carbonyl $(\mathrm{C}=\mathrm{O})$ group of spectra was present at $1766 \mathrm{~cm}^{-}$ 1 , which suggests the presence of cross-linkage between the hydroxyl group of NFC, 
$\mathrm{PVOH}$, and the carboxyl group of PAA by ester formation due to heat treatment of nanofilm at $170{ }^{\circ} \mathrm{C}$ for $45 \mathrm{~min}$ (Paralikar et al. 2008). The peak present at $1213 \mathrm{~cm}^{-1}$ also confirmed the presence of strong cross-linkage between the nano-film that was made up of NFC from banana fibre and also the biodegradable polymer of PVOH.

The above results revealed (Fig. 2) the presence of non-biodegradable plastics in the conventional film known to pose an environmental hazard. The nano-film made with biodegradable material (cellulose) from banana pseudostem along with biodegradable polymer PVA showed a strong cross-linkage between the NFC, PVOH, and PAA in turn, leading to complete biodegradability.
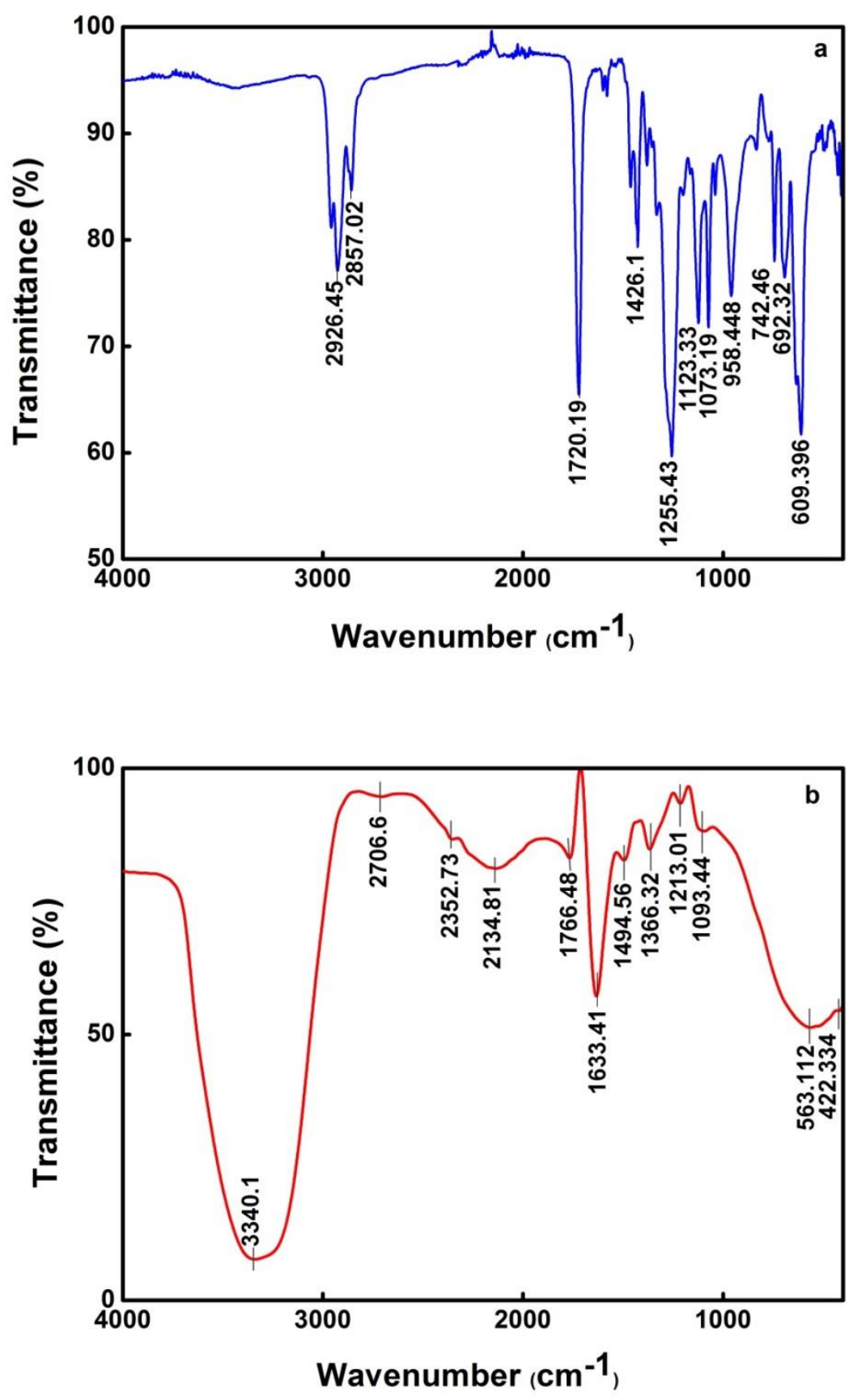

Fig. 2. FT-IR spectra of (a) conventional film and (b) nano-film 


\section{TGA}

Thermal stability and degradability of the conventional film and nano-film were determined via thermal gravimetric analysis (Fig. 3).
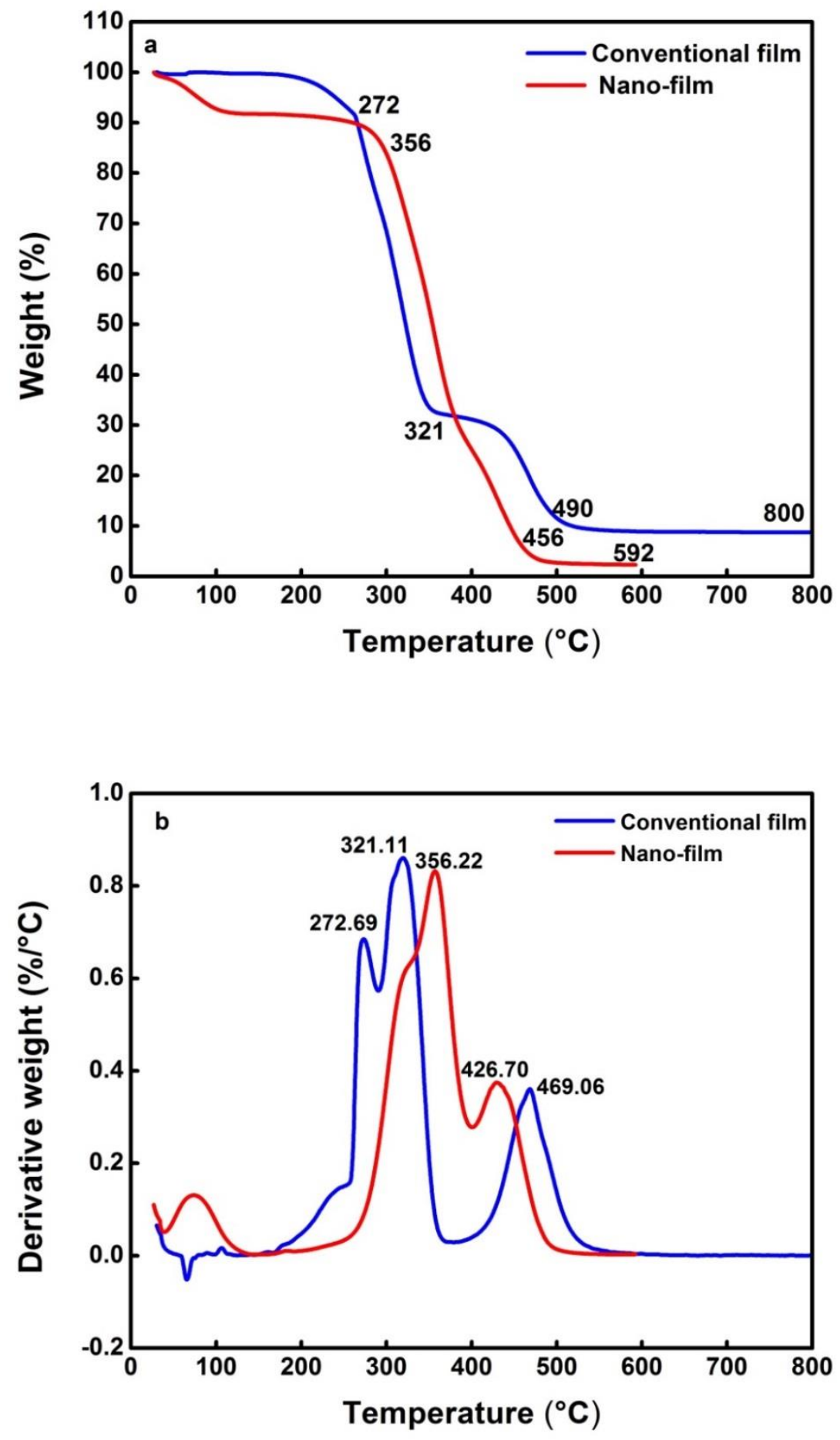

Fig. 3. (a) TG and DTG curves of conventional film and (b) TG and DTG curves of nano-film 
The thermal degradation of conventional film occurred at four stages, with a temperature region of $272,321,490$, and $800{ }^{\circ} \mathrm{C}$ with percentage weight loss of 14.59 , $48.7,86.71$, and 91.23 , respectively. In nano-film, the thermal degradation occurred at three stages, with a temperature regime of 356,456 , and $592{ }^{\circ} \mathrm{C}$ with percentage weight loss of 51,83, and 100, respectively. It was elucidated that the water evaporated at the first temperature regime and PVC degraded at the second temperature stage (Demirci et al. 2015) in the conventional film. For the nano-film, NFC degraded at the first temperature stage. The result coincided with Gopinathan et al. (2017), where PVOH and PAA degraded at the second temperature stage and this result coincided with Paralikar et al. 2008. In addition, the temperature tolerant capacity of the conventional film was 272 ${ }^{\circ} \mathrm{C}$, whereas the nano-film withstood the temperature up to $356{ }^{\circ} \mathrm{C}$ at the first stage. Moreover, the complete degradation occurred at $800{ }^{\circ} \mathrm{C}$ and $592{ }^{\circ} \mathrm{C}$ for conventional film and nano-film, respectively. This clearly showed that the thermal stability and biodegradability properties were higher in nano-film than conventional film.

Table 1. Thermal Stability and Degradability of Conventional Film

\begin{tabular}{|c|c|c|c|}
\hline Stages & $\begin{array}{c}\text { Temperature } \\
\left({ }^{\circ} \mathrm{C}\right)\end{array}$ & $\begin{array}{c}\text { Sample Remaining } \\
(\%)\end{array}$ & $\begin{array}{c}\text { Sample Degradation } \\
\text { (Weight Loss, \%) }\end{array}$ \\
\hline First degradation & 272.7 & 85.4 & 14.6 \\
\hline Second degradation & 321.1 & 51.3 & 48.7 \\
\hline Third degradation & 490.1 & 13.3 & 86.7 \\
\hline Final degradation & 800.0 & 8.77 & 91.2 \\
\hline
\end{tabular}

Table 2. Thermal Stability and Degradability of Nano-film

\begin{tabular}{|c|c|c|c|}
\hline Stages & $\begin{array}{c}\text { Temperature } \\
\left({ }^{\circ} \mathrm{C}\right)\end{array}$ & $\begin{array}{c}\text { Sample Remaining } \\
(\%)\end{array}$ & $\begin{array}{c}\text { Sample Degradation } \\
(\text { Weight Loss, \%) }\end{array}$ \\
\hline First degradation & 356.2 & 48.3 & 51.7 \\
\hline Second degradation & 456.7 & 16.7 & 83.3 \\
\hline Final degradation & 592.5 & 2.29 & 97.7 \\
\hline
\end{tabular}

\section{Gas Permeability Test}

The oxygen $\left(\mathrm{O}_{2}\right)$ and carbon dioxide $\left(\mathrm{CO}_{2}\right)$ permeability of conventional film and nano-film were measured using a manometric gas permeability tester at a temperature of $23^{\circ} \mathrm{C}$. The oxygen transmission rate of conventional film and nano-film was 21,800 $\mathrm{mL} / \mathrm{m}^{2} /$ day and $498 \mathrm{~mL} / \mathrm{m}^{2} /$ day, respectively. The carbon dioxide transmission rate of conventional film and nano-film was $26,500 \mathrm{~mL} / \mathrm{m}^{2} /$ day and $821 \mathrm{~mL} / \mathrm{m}^{2} /$ day, respectively. Oxygen is the most important factor for senescence of fruits and vegetables. A low amount of oxygen and high amount of carbon dioxide leads to an increase in the shelf life of perishable fruits and vegetables. From the results, in conventional film the transmittance rate of $\mathrm{O}_{2}$ was lower than $\mathrm{CO}_{2}$ even though the fruits were senesced earlier because the permeability of gases in the conventional film was drastically more than that of nano-film. The mechanism behind the gas permeability of nano film can be well explained through the presence of strong crosslinkage between molecules of the nanofilm such NFC, PVOH \& PAA and its even distributed nano sized particle (80 to 105 $\mathrm{nm}$ ). The presence of cross-linkage and even distribution of particle confirmed through the FT-IR and SEM characterization. When the particle in nano size the surface area will be greater, leading to high efficiency. The carbonyl ester formation leads to linked 
arrangement. Due to the strong cross-linkage and the even distribution of the nano particle may reduce the gas transmission rate (Laxmeshwar et al. 2012). Finally, the results revealed that the nano-film can be used as a natural packaging material to protect food from oxidation reactions. Therefore, shelf life and freshness of fruits were maintained when the fruits were packed using the nano-film.

\section{Tensile strength}

The elongation force and tensile strength of conventional film and nano-film were measured using the texture profile analyzer. The nano-film and the conventional film could withstand $19 \mathrm{~N} / \mathrm{mm}$ and $16 \mathrm{~N} / \mathrm{mm}$ of maximum force during elongation, respectively. The results revealed that the interaction between components of nano-film was high, which leads to better elongation property of nano-film than conventional film (Gupta et al. 2013).

\section{Thickness Analysis}

Thickness of the conventional film and the nano-film was measured by a gauge meter. The thickness of nano-film was $0.0454 \mathrm{~mm}$, which is 180 gauge and thickness of conventional film was $0.015 \mathrm{~mm}$, which is 60 gauge. The results revealed that the thickness of the nano-film was higher than the conventional film.

\section{SEM analysis}

The surface behaviour of nano-film and conventional film was characterized via SEM. The samples were sputter coated with 60/40 wt $\%$ gold alloy. The biodegradable film prepared using PVA polymer was uniformly distributed with NFC of size ranging between $80 \mathrm{~nm}$ to $105 \mathrm{~nm}$ (Fig 4.b). Because of this uniform distribution and smaller size of NFC contributed to the increased mechanical strength of the nano-film than the conventional film. Since the filler material used for a peculiar property of increasing the mechanical strength is in nano regime the film is called as nano-film, whereas conventional non-biodegradable film exhibited scattered molecules of aggregates with size 2 to $5 \mu \mathrm{m}$ (Fig 4.a).
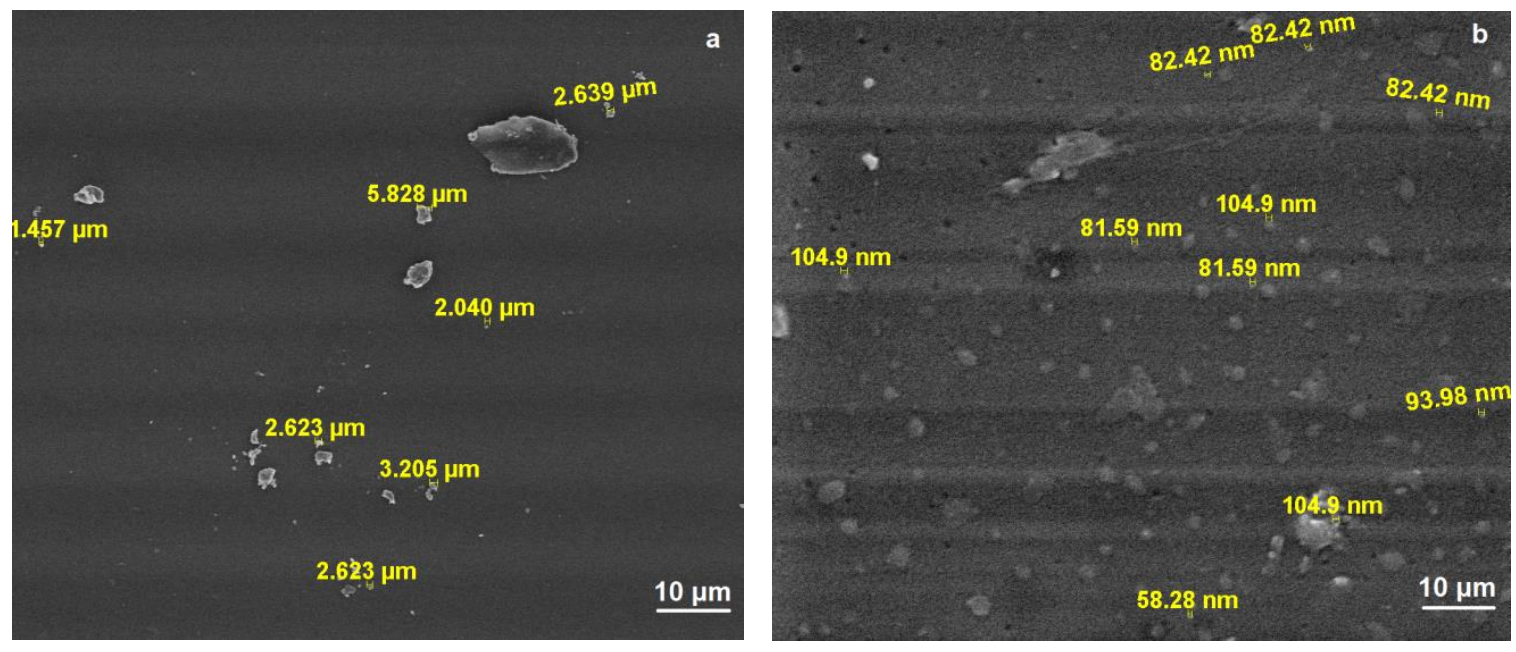

Fig. 4. SEM images of (a) conventional film and (b) nano-film 


\section{PLW}

The tomato fruits wrapped with the nano-film had extended the shelf life up to 15 days, whereas the control fruits spoiled after 9 days of storage, which clearly exhibited the shelf life extension potential. The authors observed that the PLW was 7\% and 6\% at day 9 in the control (unwrapped) and conventional film wrapped fruits, respectively, whereas in nano-film wrapped fruit a similar PLW percentage was attained at day15, which clearly indicated the weight loss prevention in fruits. This occurs due to slow respiration and transpiration process in the nano-film wrapped fruits (Sammi and Masud 2009). The highly significant PLW result $(\mathrm{P} \leq 0.05$ or $\mathrm{P}<0.01)$ was also recorded by statistical analysis.

Table 3. Physiological Weight Loss of Control (Unwrapped), Conventional Film, and Nano-film Wrapped Fruits

\begin{tabular}{|c|c|c|c|c|c|}
\hline \multicolumn{7}{|c|}{ PLW (\%) } \\
\hline Treatments & $\mathbf{3}^{\text {rd }}$ Day & $\mathbf{6}^{\text {th }}$ Day & $\mathbf{9}^{\text {th }}$ Day & $\mathbf{1 2}^{\text {th }}$ Day & $\mathbf{1 5}^{\text {th }}$ Day \\
\hline Control (unwrapped) & 2.49 & 4.86 & 7.58 & - & - \\
\hline Conventional film & 1.49 & 3.62 & 6.28 & - & - \\
\hline Nano-film & 1.60 & 2.45 & 4.09 & 6.13 & 7.28 \\
\hline $\begin{array}{c}\text { Coefficient of } \\
\text { Variation (CV) (\%) }\end{array}$ & 16.21 & 7.54 & 9.7 & 23.96 & 22.94 \\
\hline S.E.M & 0.13 & 0.12 & 0.2 & 0.21 & 0.24 \\
\hline S.E.D & 0.19 & 0.17 & 0.36 & 0.31 & 0.35 \\
\hline LSD (p < 0.05) & 0.41 & 0.37 & 0.80 & 0.67 & 0.76 \\
\hline LSD (p < 0.01) & 0.58 & 0.53 & 1.12 & 0.94 & 1.07 \\
\hline Significance level & ${ }^{* *}$ & ${ }^{* *}$ & ${ }^{* *}$ & ${ }^{* *}$ & ${ }^{* *}$ \\
\hline${ }^{*}$ Significant, ${ }^{* *}$ Highly significant, NS- Non significant \\
\hline
\end{tabular}

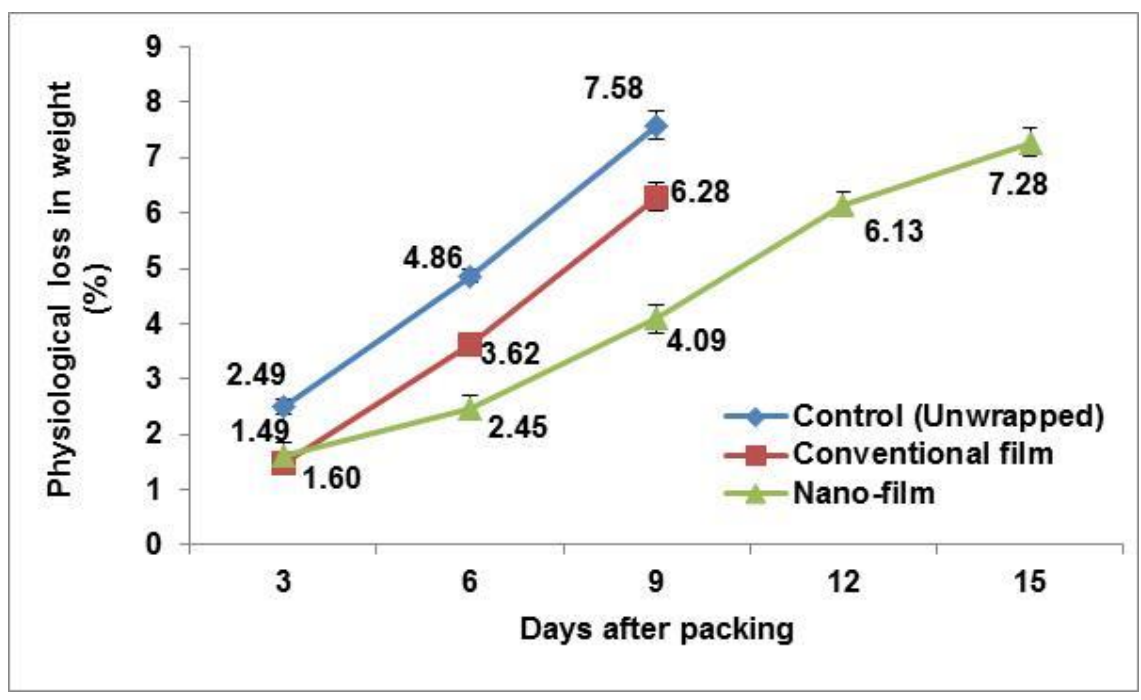

Fig. 5. Physiological weight loss of control (unwrapped), conventional film, and nano-film wrapped fruits

Firmness (N)

Firmness plays an important role in fruit quality. The firmness of the control (unwrapped) and conventional film wrapped fruits were reduced drastically on day $9 \mathrm{viz}$. 
5.56 and $6.26 \mathrm{~N}$. However, the firmness of nano-film wrapped fruits gradually decreased, and the firmness was $5.04 \mathrm{~N}$ at day 15 . The results revealed that textural changes were reduced in the tomatoes covered by nano-film compared to the control (unwrapped) and conventional film (Yang et al. 2007). The highly significant result $(\mathrm{P} \leq 0.05$ or $\mathrm{P}<0.01$ ) was also recorded by statistical analysis.

Table 4. Firmness of Control (Unwrapped), Conventional Film, and Nano-film Wrapped Fruits

\begin{tabular}{|c|c|c|c|c|c|}
\hline \multicolumn{7}{|c|}{ Firmness (N) } \\
\hline Treatments & $\mathbf{3}^{\text {rd }}$ Day & $\mathbf{6}^{\text {th }}$ Day & $\mathbf{9}^{\text {th }}$ Day & $\mathbf{1 2}^{\text {th }}$ Day & $\mathbf{1 5}^{\text {th }}$ Day \\
\hline Control (unwrapped) & 9.56 & 7.80 & 5.56 & - & - \\
\hline Conventional film & 8.88 & 7.60 & 6.26 & - & - \\
\hline Nano-film & 8.48 & 7.90 & 7.22 & 6.14 & 5.04 \\
\hline C.V. (\%) & 8.87 & 11.53 & 11.20 & 22.88 & 31.17 \\
\hline S.E.M & 0.35 & 0.40 & 0.32 & 0.20 & 0.23 \\
\hline S.E.D & 0.50 & 0.56 & 0.45 & 0.29 & 0.33 \\
\hline LSD (p<0.05) & 1.09 & 1.23 & 0.98 & 0.64 & 0.72 \\
\hline LSD (p < 0.01) & 1.53 & 1.72 & 1.38 & 0.90 & 1.01 \\
\hline Significance level & NS & NS & $*$ & $* *$ & $* *$ \\
\hline *Significant, ** Highly significant, NS- Non significant & & \\
\hline
\end{tabular}

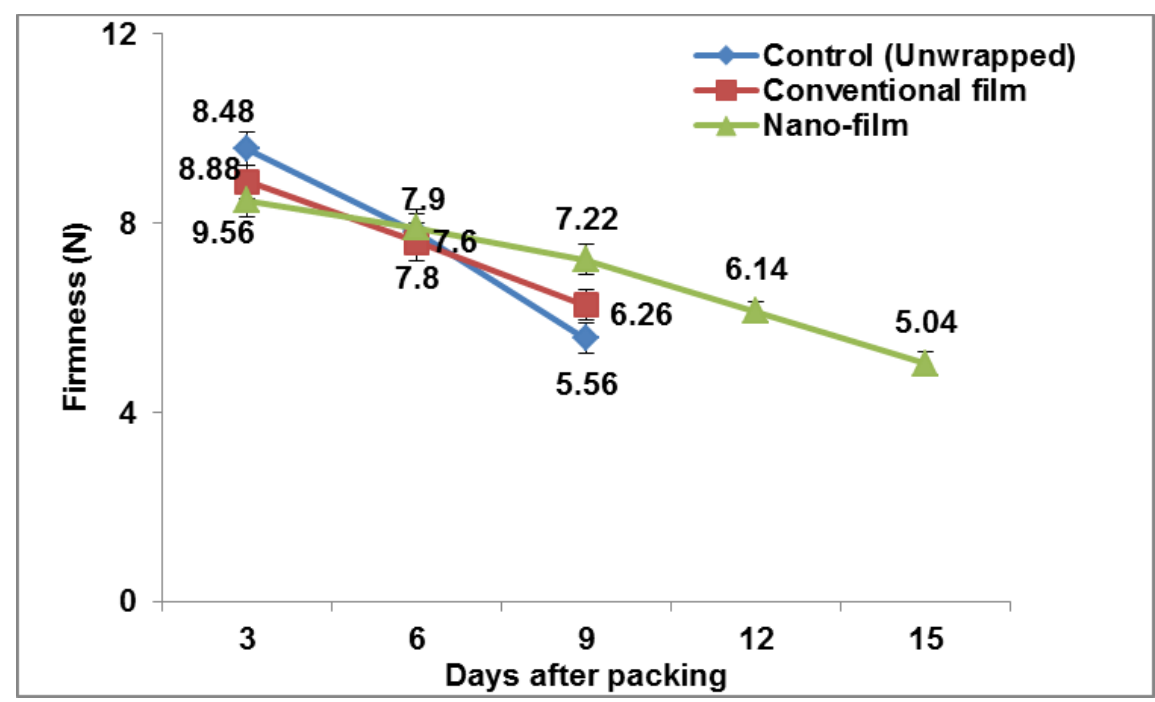

Fig. 6. Firmness of control (unwrapped), conventional film, and nano-film wrapped fruits

\section{pH}

The $\mathrm{pH}$ is of great importance in tomato flavour. On day 3 there was no significant change in the $\mathrm{pH}$ of the tomato. After that, the $\mathrm{pH}$ of control (unwrapped) and conventional film wrapped fruits increased drastically during storage. On day 9, the $\mathrm{pH}$ of control (unwrapped) and conventional film wrapped fruits viz. 4.46 and 4.60, but the 
$\mathrm{pH}$ of nano-film wrapped fruits progressively increased and the $\mathrm{pH}$ was 4.13 at day 15 . The results clearly revealed that physiochemical changes drastically occurred in the control (unwrapped) and conventional film compared to the nano-film. The statistical analysis also gave highly significant results $(\mathrm{P} \leq 0.05$ or $\mathrm{P}<0.01)$.

Table 5. The $\mathrm{pH}$ of Control (Unwrapped), Conventional Film, and Nano-film Wrapped Fruits

\begin{tabular}{|c|c|c|c|c|c|}
\hline \multicolumn{7}{|c|}{$\mathbf{p H}$} \\
\hline Treatments & $\mathbf{3}^{\text {rd }}$ Day & $\mathbf{6}^{\text {th }}$ Day & $\mathbf{9}^{\text {th }}$ Day & $\mathbf{1 2}^{\text {th }}$ Day & $\mathbf{1 5}^{\text {th }}$ Day \\
\hline Control (unwrapped) & 3.04 & 4.04 & 4.46 & - & - \\
\hline Conventional film & 3.30 & 4.26 & 4.60 & - & - \\
\hline Nano-film & 3.24 & 3.52 & 3.79 & 3.89 & 4.13 \\
\hline C.V. $(\%)$ & 11.90 & 9.80 & 9.21 & 20.01 & 19.58 \\
\hline S.E.M & 0.17 & 0.17 & 0.17 & 0.11 & 0.12 \\
\hline S.E.D & 0.24 & 0.24 & 0.24 & 0.16 & 0.17 \\
\hline LSD (p<0.05) & 0.52 & 0.53 & 0.54 & 0.35 & 0.37 \\
\hline LSD (p<0.01) & 0.73 & 0.74 & 0.76 & 0.50 & 0.52 \\
\hline Significance level & NS & $*$ & $*$ & & ${ }^{* *}$ \\
\hline${ }^{*}$ Significant, ${ }^{* *}$ Highly significant, NS- Non significant & & \\
\hline
\end{tabular}

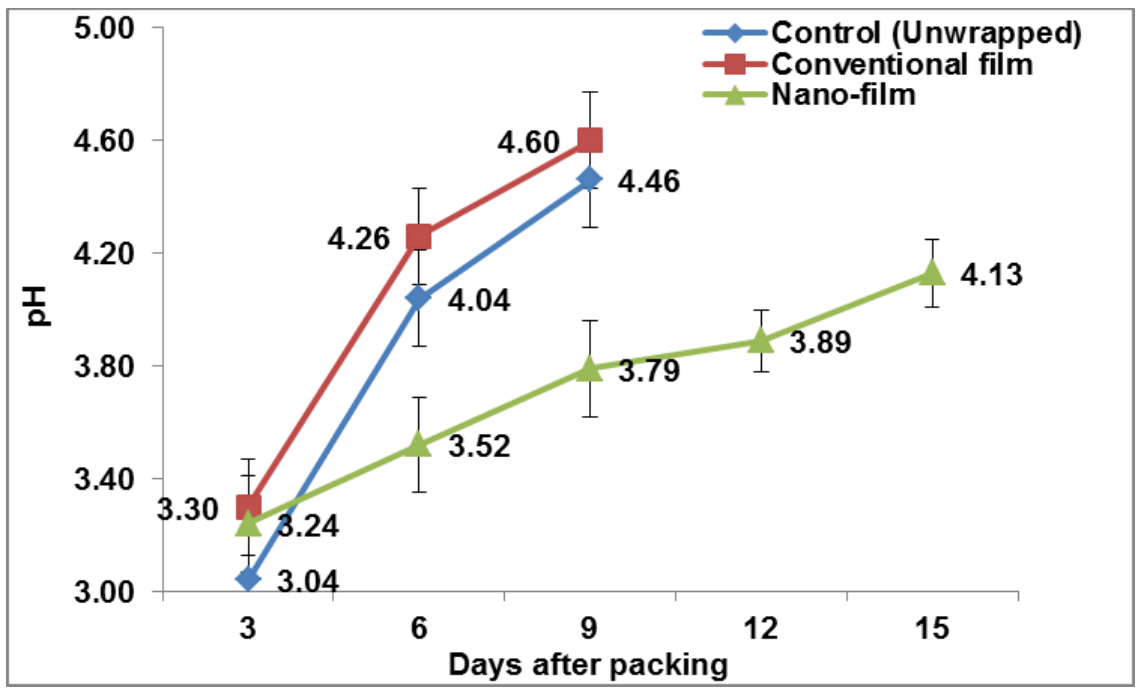

Fig. 7. pH of control (unwrapped), conventional film, and nano-film wrapped fruits

\section{Total Soluble Solid ( ${ }^{\circ}$ Brix)}

The TSS is a key factor for the quality of a tomato. The content of soluble solids gradually increased during storage in the control (unwrapped) and conventional film wrapped fruits. On the $9^{\text {th }}$ day, TSS content of the control (unwrapped) and conventional film wrapped fruits viz. 5.60 and $4.88^{\circ}$ Brix, while the TSS content of nano-film wrapped fruit was $5.49^{\circ}$ Brix on the $15^{\text {th }}$ day. The TSS content increased during storage due to hydrolysis of complex starch into simple sugar (Imlak et al. 2017). From the results, it was concluded that nano-film slowed the glycogenesis and metabolism activity of tomato during storage compared to the conventional film. The statistical analysis also gave highly significant results $(\mathrm{P} \leq 0.05$ or $\mathrm{P}<0.01)$. 
Table 6. Total Soluble Solid of Control (Unwrapped), Conventional Film, and Nano-film Wrapped Fruits

\begin{tabular}{|c|c|c|c|c|c|}
\hline \multicolumn{6}{|c|}{ TSS ( ${ }^{\circ}$ Brix) } \\
\hline Treatments & $3^{\text {rd }}$ Day & $6^{\text {th }}$ Day & $9^{\text {th }}$ Day & $12^{\text {th }}$ Day & $15^{\text {th }}$ Day \\
\hline Control (unwrapped) & 3.46 & 5.25 & 5.60 & - & - \\
\hline Conventional film & 4.08 & 4.67 & 4.88 & - & - \\
\hline Nano-film & 2.82 & 3.58 & 4.42 & 4.79 & 5.49 \\
\hline C.V. (\%) & 26.09 & 17.25 & 7.09 & 12.42 & 5.94 \\
\hline S.E.M & 0.40 & 0.34 & 0.15 & 8.86 & 4.86 \\
\hline S.E.D & 0.57 & 0.49 & 0.22 & 0.12 & 6.87 \\
\hline LSD $(p<0.05)$ & 1.24 & 1.07 & 0.48 & 0.27 & 0.14 \\
\hline LSD $(p<0.01)$ & 1.74 & 1.50 & 0.68 & 0.38 & 0.21 \\
\hline Significance level & NS & ${ }^{*}$ & ** & $\star \star \star$ & 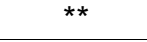 \\
\hline
\end{tabular}

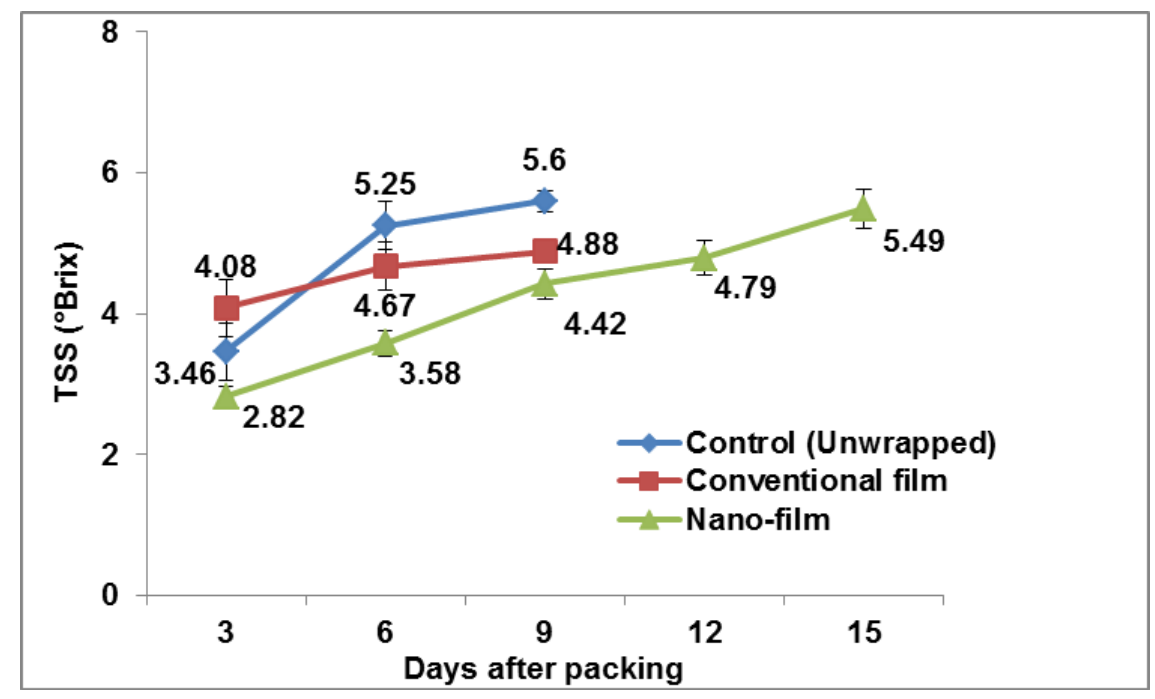

Fig. 8. TSS of control (unwrapped), conventional film, and nano-film wrapped fruits

\section{Titrable Acidity}

The titrable acidity gradually decreased during storage because the acidity is the substrate of respiration (Sualeh et al. 2016) (Table 7).

Table 7. Titrable Acidity of Control (Unwrapped), Conventional Film, and Nanofilm Wrapped Fruits

\begin{tabular}{|c|c|c|c|c|c|}
\hline \multicolumn{7}{|c|}{ Titrable Acidity (\%) } \\
\hline Treatments & $\mathbf{3}^{\text {rd }}$ Day & $\mathbf{6}^{\text {th }}$ Day & $\mathbf{9}^{\text {th }}$ Day & $\mathbf{1 2}^{\text {th }}$ Day & $\mathbf{1 5}^{\text {th }}$ Day \\
\hline Control (unwrapped) & 0.94 & 0.60 & 0.40 & - & - \\
\hline Conventional film & 0.87 & 0.66 & 0.50 & - & - \\
\hline Nano-film & 1.00 & 0.81 & 0.60 & 0.45 & 0.32 \\
\hline C.V. (\%) & 45.86 & 56.57 & 64.98 & 75.90 & 54.13 \\
\hline S.E.M & 0.19 & 0.17 & 0.15 & 5.15 & 2.63 \\
\hline S.E.D & 0.27 & 0.24 & 0.21 & 7.29 & 3.72 \\
\hline LSD (p $<0.05)$ & 0.59 & 0.54 & 0.46 & 0.15 & 8.10 \\
\hline LSD $(p<0.01)$ & 0.82 & 0.76 & 0.65 & 0.22 & 0.11 \\
\hline Significance level & NS & NS & NS & $* *$ & $* *$ \\
\hline *Significant, ${ }^{* *}$ Highly significant, NS- Non significant & & & \\
\hline
\end{tabular}


The percentage of titrable acidity for the nano-film, control (unwrapped), and conventional film wrapped fruits increased drastically on the ninth day viz. 0.40, 0.50, and 0.60 . There was no significant change in acidity up to the ninth day of storage because the tomato is basically an acidic fruit. The statistical analysis gave highly significant $(\mathrm{P} \leq 0.05$ or $\mathrm{P}<0.01)$ results because the control (unwrapped) and conventional film wrapped fruits deteriorated at day 9 .

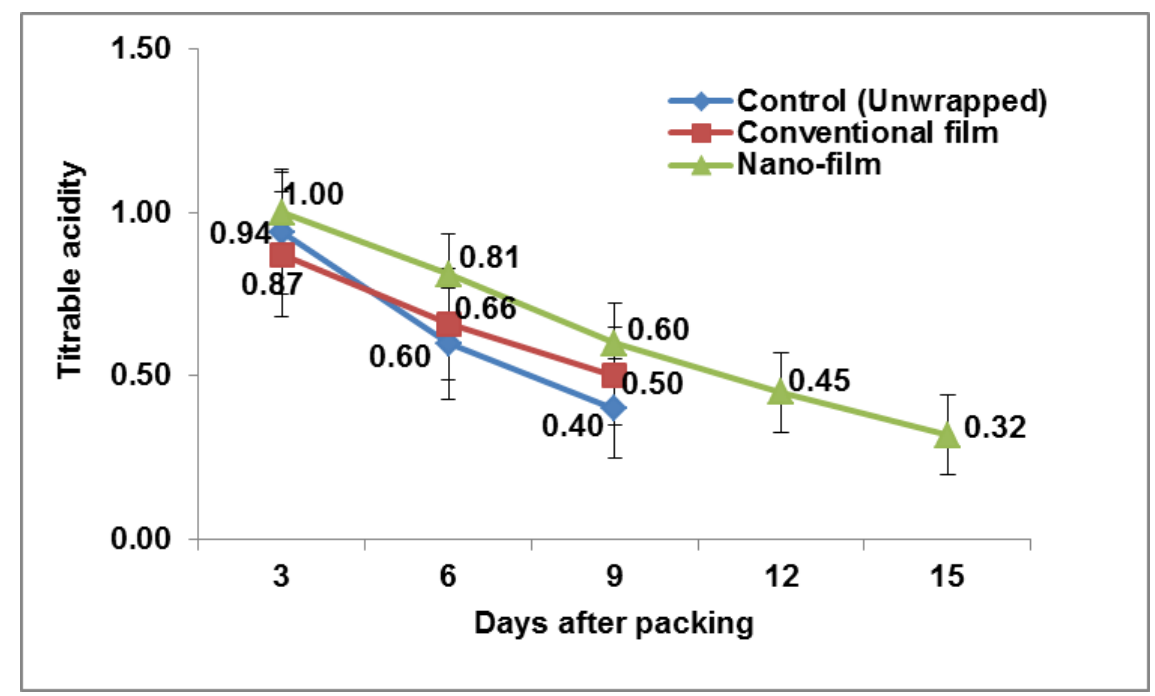

Fig. 9. Titrable acidity of control (unwrapped), conventional film, and nano-film wrapped fruits

\section{Ascorbic Acid Content (mg/100 g)}

Ascorbic acid content was drastically increased during storage. Highly significant ( $\mathrm{P} \leq 0.05$ or $\mathrm{P}<0.01)$ results were obtained by statistical analysis. The ascorbic acid content present in the control (unwrapped) and conventional film wrapped fruits was 18.00 and $17.40 \mathrm{mg} / 100 \mathrm{~g}$ at day 9, respectively, and the ascorbic acid content of nanofilm wrapped fruit was $15.96 \mathrm{mg} / 100 \mathrm{~g}$ at $15^{\text {th }}$ day. The results revealed that biochemical changes slowly occurred in nano-film wrapped fruits (Moneruzzaman et al. 2008).

Table 8. Ascorbic Acid Content of Control (Unwrapped), Conventional Film, and Nano-film Wrapped Fruits

\begin{tabular}{|c|c|c|c|c|c|}
\hline \multicolumn{6}{|c|}{ Ascorbic Acid (mg/100 g) } \\
\hline Treatments & $3^{\text {rd }}$ Day & $6^{\text {th }}$ Day & $9^{\text {th }}$ Day & $12^{\text {th }}$ Day & $15^{\text {th }}$ Day \\
\hline Control (unwrapped) & 9.70 & 13.70 & 18.00 & - & - \\
\hline Conventional film & 10.84 & 14.40 & 17.40 & - & - \\
\hline Nano-film & 9.46 & 10.16 & 11.32 & 13.82 & 15.96 \\
\hline C.V. (\%) & 21.56 & 18.76 & 18.96 & 48.62 & 38.38 \\
\hline S.E.M & 0.95 & 1.06 & 1.32 & 1.00 & 0.91 \\
\hline S.E.D & 1.35 & 1.51 & 1.86 & 1.41 & 1.29 \\
\hline LSD $(p<0.05)$ & 2.95 & 3.29 & 4.07 & 3.08 & 2.81 \\
\hline $\operatorname{LSD}(p<0.01)$ & 4.14 & 4.62 & 5.70 & 4.32 & 3.94 \\
\hline Significance level & NS & * & ${ }^{\star *}$ & $\star \star \star *$ & $\star \star \star *$ \\
\hline
\end{tabular}




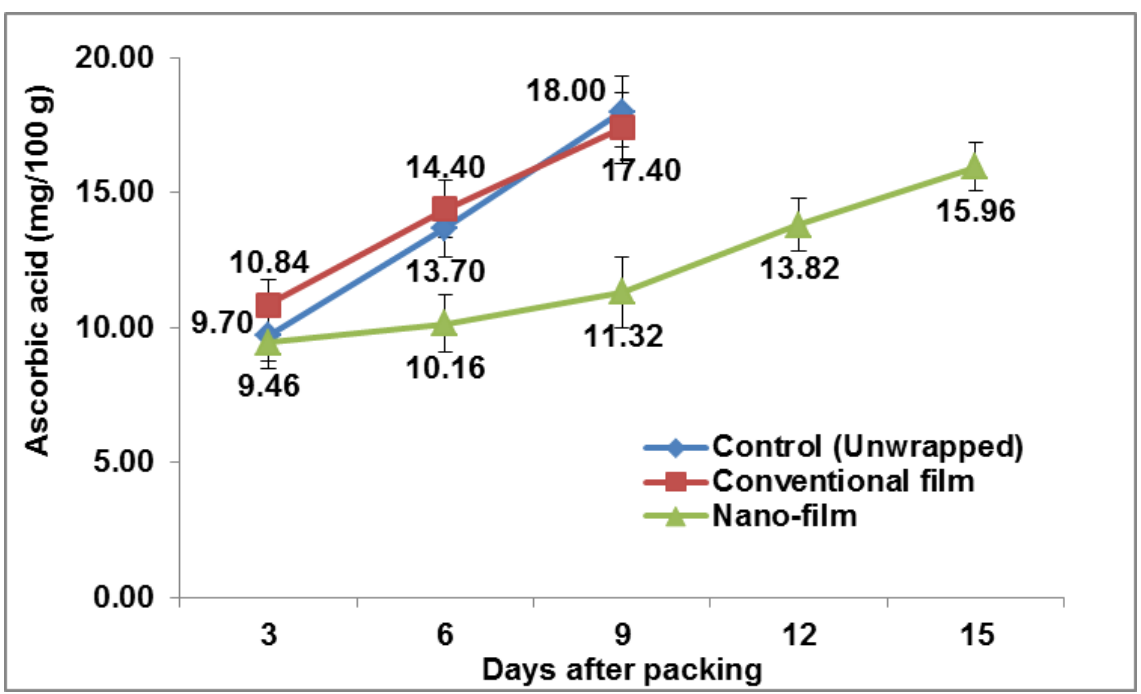

Fig. 10. Ascorbic acid content of control (unwrapped), conventional film, and nano-film wrapped fruits

\section{Total Sugars Percentage}

The flavour of tomato is determined by the presence of total sugar. Highly significant $(\mathrm{P} \leq 0.05$ or $\mathrm{P}<0.01)$ results were obtained by statistical analysis. The total sugar content present in the control (unwrapped) and conventional film wrapped fruits were 5.24 and $6.31 \%$ at day 9 and the total sugar content of nano-film wrapped fruit was $5.38 \%$ at day 15 . The results revealed that the starch to sugar conversion metabolism process slowly occurred in nano-film wrapped fruits (Moneruzzaman et al. 2008).

Table 9. Total Sugar Content of Control (unwrapped), Conventional Film, and Nano-film Wrapped Fruits

\begin{tabular}{|c|c|c|c|c|c|}
\hline \multicolumn{7}{|c|}{ Total Sugar (\%) } \\
\hline Treatments & $\mathbf{3}^{\text {rd }}$ Day & $\mathbf{6}^{\text {th }}$ Day & $\mathbf{9}^{\text {th }}$ Day & $\mathbf{1 2}^{\text {th }}$ Day & $\mathbf{1 5}^{\text {th }}$ Day \\
\hline Control (unwrapped) & 3.38 & 4.22 & 5.24 & - & - \\
\hline Conventional film & 3.65 & 5.11 & 6.31 & - & - \\
\hline Nano-film & 3.09 & 3.41 & 3.71 & 4.87 & 5.38 \\
\hline C.V. $(\%)$ & 11.06 & 9.20 & 8.22 & 14.53 & 12.90 \\
\hline S.E.M & 0.16 & 0.17 & 0.18 & 0.10 & 0.10 \\
\hline S.E.D & 0.23 & 0.24 & 0.26 & 0.14 & 0.14 \\
\hline LSD (p<0.05) & 0.51 & 0.53 & 0.57 & 0.32 & 0.31 \\
\hline LSD (p<0.01) & 0.72 & 0.75 & 0.80 & 0.45 & 0.44 \\
\hline Significance level & NS & ${ }^{* *}$ & ${ }^{* *}$ & ${ }^{* *}$ & ${ }^{* *}$ \\
\hline * Significant, ${ }^{* *}$ Highly significant, NS- Non significant & & \\
\hline
\end{tabular}

\section{Reducing Sugars Percentage}

The highly significant $(\mathrm{P} \leq 0.05$ or $\mathrm{P}<0.01)$ results were obtained by statistical analysis. The reducing sugar content present in the control (unwrapped) and conventional film wrapped fruits was 5.70 and $5.80 \%$ at the ninth day, and the reducing sugar content of nano-film wrapped fruit was $5.92 \%$ at the $15^{\text {th }}$ day. The results revealed that the sugar content was drastically increased and the deterioration occurred quickly in the control (unwrapped) and the conventional film wrapped fruits than nano-film wrapped fruits (Moneruzzaman et al. 2008). 
Table 10. Reducing Sugar Content of Control (Unwrapped), Conventional Film, and Nano-film Wrapped Fruits

\begin{tabular}{|c|c|c|c|c|c|}
\hline \multicolumn{7}{|c|}{ Reducing Sugar (\%) } \\
\hline Treatments & $\mathbf{3}^{\text {rd }}$ Day & $\mathbf{6}^{\text {th }}$ Day & $\mathbf{9}^{\text {th }}$ Day & $\mathbf{1 2}^{\text {th }}$ Day & $\mathbf{1 5}^{\text {th }}$ Day \\
\hline Control (unwrapped) & 2.87 & 4.40 & 5.70 & - & - \\
\hline Conventional film & 2.87 & 4.56 & 5.80 & - & - \\
\hline Nano-film & 2.56 & 3.02 & 3.57 & 4.60 & 5.92 \\
\hline C.V. (\%) & 19.98 & 13.70 & 12.71 & 23.81 & 16.07 \\
\hline S.E.M & 0.24 & 0.24 & 0.28 & 0.16 & 0.14 \\
\hline S.E.D & 0.35 & 0.34 & 0.40 & 0.23 & 0.20 \\
\hline LSD (p $<0.05)$ & 0.76 & 0.75 & 0.87 & 0.50 & 0.43 \\
\hline LSD (p<0.01) & 1.07 & 1.05 & 1.23 & 0.70 & 0.61 \\
\hline Significance level & NS & $\star *$ & ${ }^{* *}$ & $* *$ & $* *$ \\
\hline *Significant, ${ }^{* *}$ Highly significant, NS- Non significant & & & \\
\hline
\end{tabular}

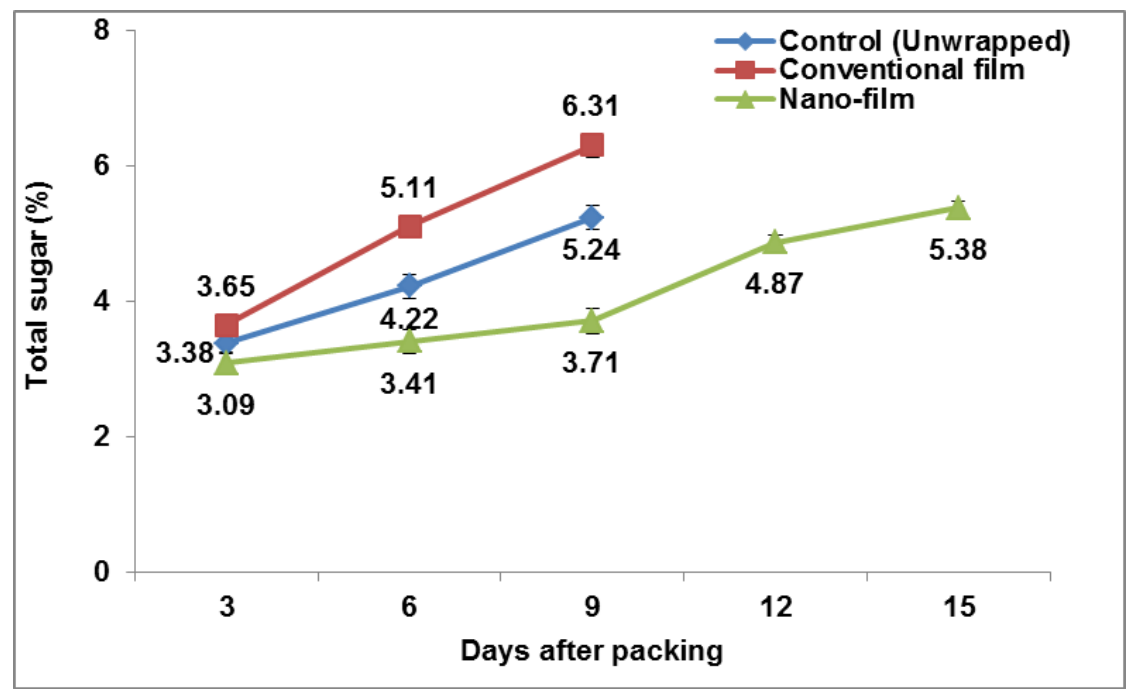

Fig. 11. Total sugar content of control (unwrapped), conventional film, nano-film wrapped fruits

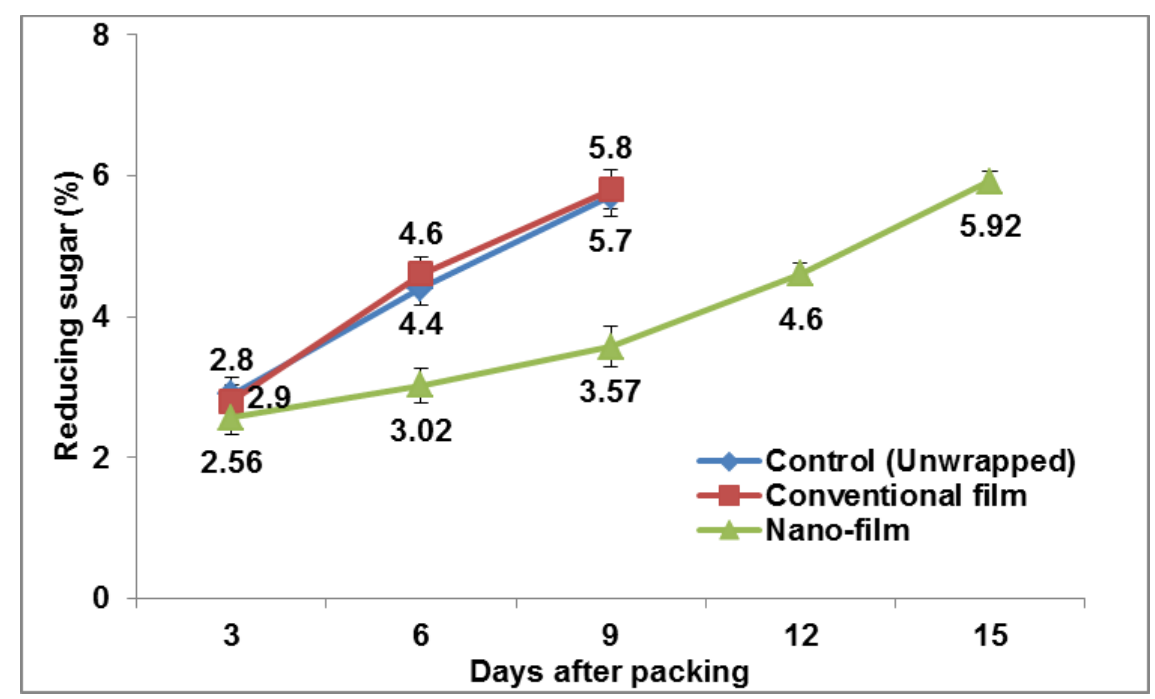

Fig. 12. Reducing sugar content of control (unwrapped), conventional film, and nano-film wrapped fruits 


\section{Visual Observation}

The shelf life of tomatoes wrapped in nano-film stayed fresh for 15 days, the conventional film wrapped fruits for 8 days, and the control (without wrapping) fruits for 6 days. Overall, the data suggested that nano-film synthesis from nanofibrillated cellulose of banana pseudostem wrapped fruits were better in quality, and the shelf life was extended up to seven days compared to conventional film and nine days more than the control (unwrapped).
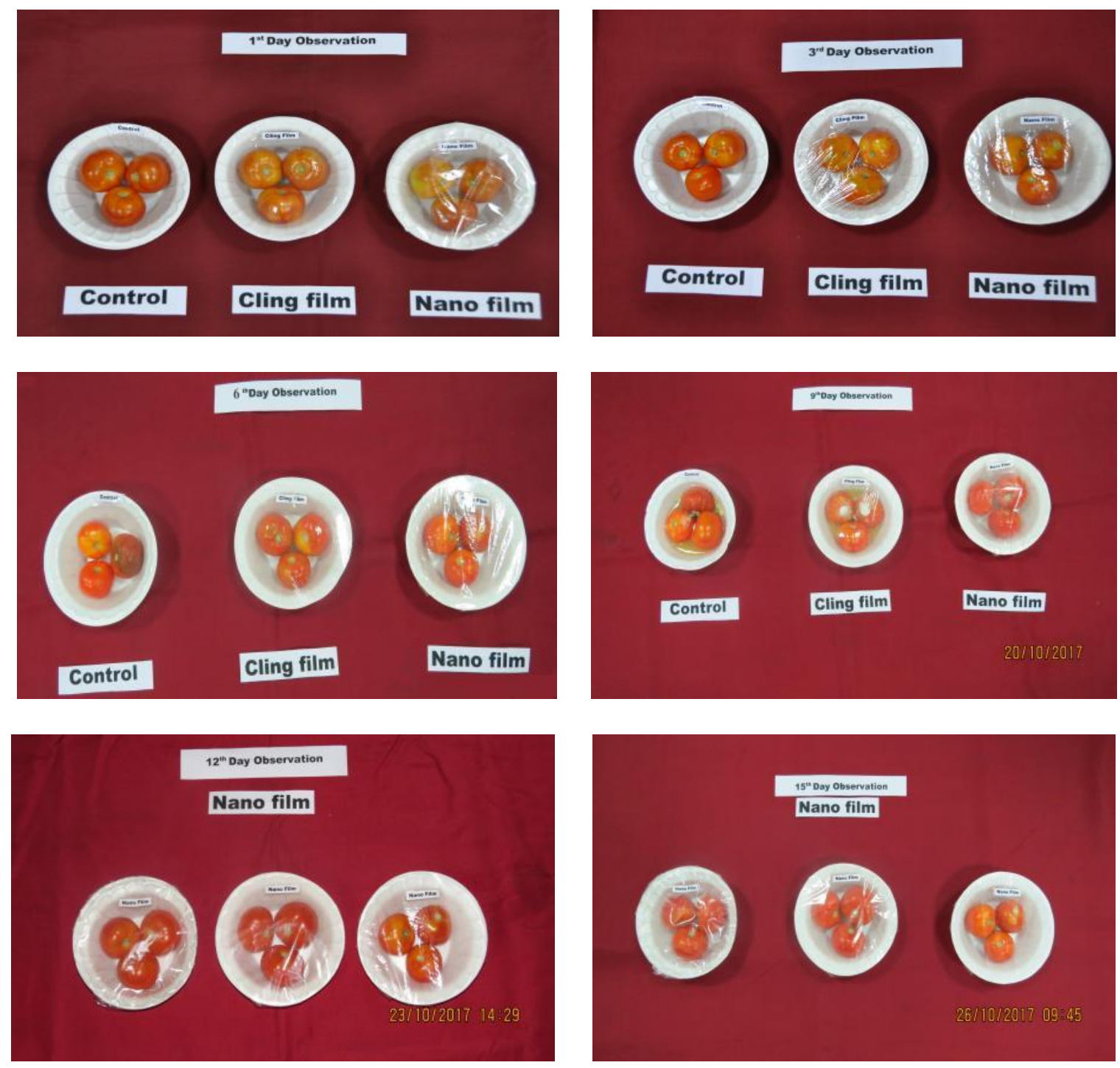

Fig. 13. Visual observation of control (unwrapped), conventional film, and nano-film wrapped fruits

\section{Statistical Analysis}

The nano-film developed from NFC of banana pseudostem fibre had more efficient characteristics than the conventional film, such as UV protectant, thermally stable up to $356{ }^{\circ} \mathrm{C}$, and high tensile strength. The shelf life study also revealed highly significant results $(\mathrm{P}<0.05$ or $\mathrm{P}<0.01)$. The nano-film wrapped fruits showed better results in maintaining high levels in firmness $(\mathrm{N})$, total soluble solids $\left({ }^{0} \mathrm{Brix}\right)$, titrable 
acidity, ascorbic acid (mg/100 g), and low levels in physiological loss of weight (\%), $\mathrm{pH}$, total sugar (\%), and reducing sugar (\%). Finally, the results revealed that development of a nano-film from biowaste of banana pseudostem NFC had the capability of preserving tomato fruits for a period of 15 days under ambient storage conditions.

\section{CONCLUSIONS}

1. Nano-film was successfully developed from nanofibrillated cellulose of banana pseudostem fibre with a combination of polyvinyl alcohol $(5 \%)$ and polyacrylic acid (5\%) using a solvent casting method.

2. The synthesized nano-film developed from banana pseudostem possessed excellent qualities, such as UV protectant, strong cross-linkage, it was thermally stable up to $356^{\circ} \mathrm{C}$, and possessed a high tensile strength compared to conventional film.

3. To assess the protective quality of the newly developed nano-film, tomato fruits were covered, and the shelf life was determined using a standard set of physiological and biochemical attributes. The shelf life of tomatoes wrapped in the nano-film stayed fresh for 15 days, the conventional film wrapped fruits stayed fresh for 8 days, and the control (without wrapping) fruit stayed fresh for 6 days. Overall, the data suggested that the nano-film, developed from banana pseudostem, wrapped fruits were better in quality and the shelf life was extended up to seven days compared to the conventional film and nine days more than the control (unwrapped).

\section{ACKNOWLEDGEMENTS}

The authors acknowledge the financial support provided by the Global Affairs Canada and International Development Research Center, Canada to undertake the research program.

\section{REFERENCES CITED}

Aider, M. (2010). "Chitosan application for active bio-based films production and potential in the food industry," LWT-Food Science and Technology 43(6), 837-842. DOI: 10.1016/j.lwt.2010.01.021

Al-Turaif, H. A. (2013). "Relationship between tensile properties and film formation kinetics of epoxy resin reinforced with nanofibrillated cellulose," Progress in Organic Coatings 76(2-3), 477-481. DOI: 10.1016/j.porgcoat.2012.11.001

Braun, D. (2004). "Poly (vinyl chloride) on the way from $19^{\text {th }}$ century to the $21 \mathrm{st}$ century," Journal of Polymer Science Part A: Polymer Chemistry 42(3), 578-586. DOI: 10.1002/pola.10906

Brinchi, L., Cotana, F., Fortunati, E., and Kenny, J. M. (2013). "Production of nano crystalline cellulose from lignocellulosic biomass: Technology and applications," Carbohydrate Polymers 94(1), 154-169. DOI: 10.1016/j. carbpol.2013.01.033 
Carbone, M., Donia, D. T., Sabbatella, G., and Antiochia, R. (2016). "Silver nanoparticles in polymeric matrices for fresh food packaging," Journal of King Saud University-Science 28(4), 273-279. DOI: 10.1016/J.JKSUS.2016.05.004

Demirci, N., Demirel, M., and Dilsiz, N. (2015). "Graft-polymerization of N-vinyl-2pyrolidone, allylamine and acrylic acid on to PVC film by plasma treatments," Journal of Multidisciplinary Engineering Science Studies 1(1), 2912-1309.

Eichhorn, S. J., Dufresne, A., Aranguren, M., Marcovich, N. E., Capadona, J. R., and Rowan, S. J. (2010). "Review: Current international research into cellulose nanofibres and nanocomposites," Journal of Materials Science 45(1), 1-33.

Endo, R., Saito, T., and Isogai, A. (2013). "TEMPO-oxidized cellulose nanofibril/poly (vinyl alcohol) composite drawn fibers," Polymer 54(2), 935-941. DOI: 10.1016/j.polymer.2012.12.035

Fujisawa, S., Ikeuchi, T., Takeuchi, M., Saito, T., and Isogai, A. (2012). "Superior reinforcement effect of TEMPO-oxidized cellulose nanofibrils in polystyrene matrix: Optical, thermal, and mechanical studies," Biomacromolecules 13(7), 2188-2194. DOI: 10.1021/BM300609C

Gopinathan, P., Subramanian, K. S., Paliyath, G., and Subramanian, J. (2017). "Genotypic variations in characteristics of nano-fibrillated cellulose derived from banana pseudostem," BioResources 12(4), 6984-7001.

DOI: 10.15376/biores. 12.4.6984-7001

Gupta, B., Agarwal, R., and Sarwar Alam, M. (2013). "Preparation and characterization of polyvinyl alcohol-polyethylene oxide-carboxymethyl cellulose blend membranes," Journal of Applied Polymer Science 127(2), 1301-1308. DOI: 10.1002/app.37665

He, X., and Hwang, H. M. (2016). "Nanotechnology in food science: Functionality, applicability, and safety assessment," Journal of Food and Drug Analysis 24(4), 671681. DOI: 10.1016/j.jfda.2016.06.001

Imlak, M., Randhawa, M. A., Hassan, A., Ahmad, N., and Nadeem, M. (2017). "Postharvest shelf life extension and nutritional profile of Thompson seedless table grapes under calcium chloride and modified atmospheric storage," Journal of Food Processing and Technology 8(648), 1-6. DOI: 10.4172/2157-7110.1000648

Klemm, D., Heublein, B., Fink, H. P., and Bohn, A. (2005). "Cellulose: Fascinating biopolymer and sustainable raw material," Angewandte Chemie (International Edition) 44(22), 3358-3393. DOI: 10.1002/ anie.200460587

Laxmeshwar, S. S., Madhu Kumar, D. J., Viveka, S., and Nagaraja, G. K. (2012). "Preparation and properties of biodegradable film composites using modified cellulose fibre-reinforced with PVA," International Scholarly Research Network Polymer Science 2012, Article ID 154314. DOI: 10.5402/2012/154314

Littunen, K., Hippi, U., Saarinen, T., and Seppala, J. (2013). "Network formation of nanofibrillated cellulose in solution blended poly (methyl methacrylate) composites," Carbohydrate Polymers 91(1), 183-190. DOI: 10.1016/j.carbpol.2012.08.032

Meeker, J. D., Sathyanarayana, S., and Swan, S. H. (2009). "Phthalates and other additives in plastics: Human exposure and associated health outcomes," Philosophical Transactions of the Royal Society of London B: Biological Science 364(1526), 2097-2113. DOI: 10.1098/rstb.2008.0268

Moneruzzaman, K. M., Hossain, A. B. M. S., Sani, W., and Saifuddin, M. (2008). "Effect of stages of maturity and ripening conditions on the biochemical characteristics of tomato," American Journal of Biochemistry and Biotechnology 4(4), 336-344. 
Nakagaito, A. N., and Yano, H. (2005). "Novel high-strength biocomposites based on microfibrillated cellulose having nano-order- unit web-like network structure," Applied Physics A 80(1), 155-159. DOI: 10.1007/s00339-003-2225-2

Oehlmann, J., Schulte-Oehlmann, U., Kloas, W., Jagnytsch, O., Lutz, I., Kusk, K. O., Wollenberger, L., Santos, E. M., Paull, G. C., Van Look, K. J., et al. (2009). "A critical analysis of the biological impacts of plasticizers on wildlife," Philosophical Transactions of the Royal Society B: Biological Sciences 364(1526), 2047-2062. DOI: $10.1098 /$ rstb.2008.0242

Paralikar, S. A., Simonsen, J., and Lombardi, J. (2008). "Poly(vinyl alcohol)/cellulose nanocrystal barrier membranes," Journal of Membrane Science 320(1-2), 248-258. DOI: 10.1016/j.memsci.2008.04.009

Phisalaphong, M., and Jatupaiboon, N. (2008). "Biosynthesis and characterization of bacteria cellulose-chitosan film," Carbohydrate Polymers 74(3), 482-488. DOI: 10.1016/j.carbpol.2008.04.004

Rajan, R., Skrifvars, M., and Jarvela, P. (2014). "Lactic acid polymers: Synthesis, properties, and applications," in: Handbook of Green Materials, World Scientific Publishing Co., Pte Ltd., Singapore, pp. 49-65. DOI: 10.1142/9789814566469_0050

Rolle, R. S. (2006). Postharvest Management of Fruit and Vegetables in the Asia-Pacific Region, Asian Productivity Organization, Tokyo, Japan.

Sammi, S., and Masud, T. (2009). "Effect of different packaging systems on the quality of tomato (Lycopersicon esculentum var. Rio Grande) fruits during storage," International Journal of Food Science + Technology 44(5), 918-926. DOI: 10.1111/j.1365-2621.2007.01649.x

Shahnawaz, M., Sheikh, S. A., Soomro, A. H., Panhwar, A. A., and Khaskheli, S. G. (2012). "Quality characteristics of tomatoes (Lycopersicon esculentum) stored in various wrapping materials," African Journal of Food Science and Technology 3(5), 123-128.

Singh, P. K., Jairath, G., and Ahlawat, S. S. (2016). "Nanotechnology: A future tool to improve quality and safety in meat industry," Journal of Food Science and Technology 53(4), 1739-1749. DOI: 10.1007/s13197-015-2090-y

Somogyi, M. (1952). "Determination of reducing sugars by Nelson-Somogyi method," Journal of Biological Chemistry 195, 19-23.

Spoljaric, S., Salminen, A., Luong, N. D., and Seppala, J. (2013). "Crosslinked nanofibrillated cellulose: Poly (acrylic acid) nanocomposite films; enhanced mechanical performance in aqueous environments," Cellulose 20(6), 2991-3005. DOI: $10.1007 / \mathrm{s} 10570-013-0061-\mathrm{x}$

Stiller, B. (2008). The Effect of Montmorillonite Nanoclay on Mechanical and Barrier Properties of Mung Bean Starch Films, Master's Thesis, Clemson University, Clemson, SC, USA.

Sualeh, A., Daba, A., Kiflu, S., and Mohammed, A. (2016). "Effect of storage conditions and packing materials on shelf life of tomato," Food Science and Quality Management 56, 65-67.

Talsness, C. E., Andrade, A. J., Kuriyama, S. N., Taylor, J. A., and Vom Saal, F. S. (2009). "Components of plastic: Experimental studies in animals and relevance for human health," Philosophical Transactions of the Royal Society of London B: Biological Sciences 364(1526), 2079-2096. DOI: 10.1098/rstb.2008.0281

Thompson, R. C., Moore, C. J., Vom Saal, F. S., and Swan, S. H. (2009). "Plastics, the environment and human health: Current consensus and future trends," Philosophical 
Transactions of the Royal Society B: Biological Sciences 364(1526), 2153-2166. DOI: $10.1098 /$ rstb.2009.0053

Thompson, R. C., Swan, S. H., Moore, C. J., and Vom Saal, F. S. (2009). "Our plastic age," Philosophical Transactions of the Royal Society B: Biological Series 364(1526), 1973-1976. DOI: 10.1098/rstb.2009.0054

Trifol Guzman, J. (2016). Hybrid Nanocellulose/Nanoclay Composites for Food Packaging Applications, Ph.D. Thesis, Danmarks Tekniske Universitet, Kongens Lyngby, Denmark.

Yang, Z., Zheng, Y., Cao, S., Tang, S., Ma S., and Li, N. A. (2007). "Effects of storage temperature on textural properties of Chinese bayberry fruit," Journal of Texture Studies 38(1), 166-177. DOI: 10.1111/j.1745-4603.2007.00092.x

Zimmermann, T., Pohler, E., and Geiger, T. (2004). 'Cellulose fibrils for polymer reinforcement," Advanced Engineering Materials 6(9), 754-761. DOI: 10.1002/adem.200400097

Article submitted: September 12, 2019; Peer review completed: February 22, 2020; Revised version received and accepted: March 6, 2020; Published: March 10, 2020. DOI: $10.15376 /$ biores. 15.2.2882-2905 